\title{
Evaluation of the Periodic Examination of Physicians Working in a Training and Research Hospital Regarding Malignancy Risk
}

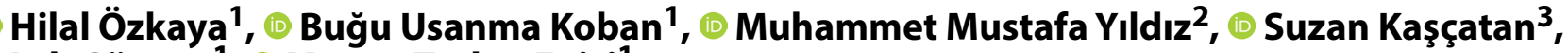 \\ Işık Gönenç ${ }^{1}$, (i) Memet Taşkın Egici ${ }^{1}$
}

${ }^{1}$ Department of Family Medicine, University of Health Sciences, Hamidiye Faculty of Medicine, Haydarpasa Numune Health Application and Research Center, Istanbul, Turkey

2Palliative Care Center, University of Health Sciences, Hamidiye Faculty of Medicine, Haydarpasa Numune Health Application and Research Center, Istanbul, Turkey

${ }^{3}$ Department of Occupational Health, University of Health Sciences, Hamidiye Faculty of Medicine, Haydarpasa Numune Health Application and Research Center, Istanbul, Turkey

\begin{abstract}
Introduction: Employee health was assured by regulation no. 27897 on 6 April 2011, in our country, Turkey. Health workers are periodically examined and controlled according to the risk in their duties. In this study, we aimed to analyze periodic examinations of physicians working in an educational research hospital and determine the findings that may pose a risk for malignant diseases.

Methods: Periodic health examination (PHE) files of 227 physicians working in Haydarpaşa Numune Training and Research Hospital between 01.06.2018-31.12.2018 were examined in this study.

Results: The files of 227 physicians who gave consent for the periodic examination were studied. Of the 221 physicians whose data were complete, 125 were female (56.6\%), and 96 were male (43.4\%). When smoking was questioned regarding the etiology of malignancy, the number of physicians smoking was 32 (14.1\%), and no statistically significant difference was found between the genders. When another risk factor obesity rates were examined, 20.7\% were overweighed (n: 47), 3.5\% were obese (n: 8), and $0.4 \%$ were morbidly obese (n: 1). Male physicians were more likely to be overweighed or obese, and the difference was statistically significant compared to women. The rates of other findings that may be risk factors were much lower.

Discussion and Conclusion: When PHE files are analyzed regarding risk factors that may be involved in the etiology of malignancy in the literature, it is concluded that physicians have positive results according to the data of the world and our country. Keywords: Employee health; periodic examination; malignant diseases; malignancy risk assessment.
\end{abstract}

$\mathrm{R}_{\mathrm{t}}$ eduction of infections and prolongation of life all over the world, especially in developed and developing countries, have led to changes in the prevalence of chronic diseases and causes of mortality, especially in the course of the last fifty years. When we look at the causes of mortal- ity in recent years, it is seen that infectious diseases have ranked lower in the list, whereas chronic causes, such as COPD and malignancy, have increased to the upper ranks. Respiratory cancers, which were the $9^{\text {th }}$ most common cause of death in 2000, progressed to the 6th place in 2016,

Correspondence (İletişim): Hilal Özkaya, M.D. Saglik Bilimleri Universitesi Hamidiye Tip Fakultesi, Haydarpasa Numune Saglik Uygulama ve Arastirma Merkezi, Aile Hekimligi Klinigi, Istanbul, Turkey

Phone (Telefon): +90 5339348730 E-mail (E-posta): ozkaya2012@gmail.com

Submitted Date (Başvuru Tarihi): 24.10.2019 Accepted Date (Kabul Tarihi): 04.11.2019

Copyright 2020 Haydarpaşa Numune Medical Journal

OPEN ACCESS This is an open access article under the CC BY-NC license (http://creativecommons.org/licenses/by-nc/4.0/) 
after 16 years ${ }^{[1]}$. Again in 2018, the number of cancers in the world, which was 18.1 million, is estimated to increase

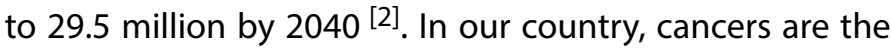
second most common cause of death (19.7\%), all the respiratory cancers ranking first (30.8\%) among malignancies, followed by lymphoid and hematopoietic, stomach, colon and pancreas cancers, respectively ${ }^{[3]}$.

When we look at the etiology of all cancers in general, smoking, alcohol, unhealthy nutrition, polluted air and other toxins, genetic factors, some infections, obesity, sedentary life and sunlight exposure factors seem to be predominant [4]. Employees of each profession may carry some risks for certain malignancies due to their personal characteristics as well as their exposure to work life.

Article 7 of the "Regulation on Ensuring Patient and Employee Safety", dated 6th of April 2011 and no. 27897, includes occupational health and safety practices of health workers duties of health institutions, in our country [5].

Routine health screening in hospitals is carried out annually and for employees working in risky units, it is carried out every six months. The routine screening includes personal history, family history, anthropometric data (height, weight), medical history, questioning harmful habits and routine physical examination, eye examination, PPD and audiometry test. Routine laboratory tests include infectious disease screening, complete blood count and kidney and liver function tests. Imaging methods include electrocardiography with PA chest X-ray. People who work in risky units are asked for additional examinations specific to the risk factor for the unit they work.

Medicine is a profession that requires serving devotedly with long working hours and workload. With a paternalistic approach since Hippocrates, it is seen that the physician who takes care of a patient's health puts the health care and check-ups about him in the background ${ }^{[6]}$. When we look at the literature on the health of a physician, it is seen that issues, such as burnout, sleeping problems and violence directed to physicians come up, but the data in the literature are limited ${ }^{[7-9]}$. To our knowledge, no study was encountered on the characteristics of the physicians that might carry malignancy risk. In our study, we planned the frequency and analysis of the factors that may carry the risk of malignancy in the data of the physicians whose periodical health screening took place in the hospitals.

\section{Materials and Methods}

Our research is cross-sectional and single-centered and includes the physicians working at the Haydarpaşa Nu- mune Training and Research Hospital of Health Sciences University in 2018. For this study, the files of a total of 227 physicians who actively served in the hospital between 01.06.2018-31.12.2018 and had periodic health screening were considered. An analysis of the physicians whose risk factors were only present in the data file and may be included in the etiology of malignancy, such as medical history and family history, demographic and anthropometric data, physical examination findings, PA chest $x$-ray and for risk groups additional tests, such as thyroid ultrasonography (USG), peripheral smear and pulmonary function test (PFT) is planned.

Before this study, the administrative permission of Haydarpaşa Numune Training and Research Hospital, dated 17.09.2018, was obtained and the working process was carried out in accordance with the Helsinki Declaration.

The data were evaluated in the IBM SPSS 22.0 package program and frequency, descriptive analysis, chi-square and regression analysis were used to analyze the data, and $\mathrm{p}<0.05$ was considered statistically significant.

\section{Results}

It was observed that the physicians working in the hospital and participating in the periodic examination were $56.6 \%$ female ( $\mathrm{n}: 125), 43.4 \%$ male (n: 96$)$, and the average age was $35.20 \pm 10.03$ (Table 1).

It was determined that physicians were $58.6 \%$ post-graduates (general practitioner or residents, n: 133) and 39.2\% were senior physicians ( $n: 89)$. When the marital status was examined, it was seen that $41.1 \%$ of men were single ( $\mathrm{n}$ : 39 ), $58.9 \%$ were married ( $\mathrm{n}: 56$ ), and female physicians were $45.6 \%$ single and $54.4 \%$ were married ( $n: 68$ ) and statistically no significant difference was detected ( $p>0.05$ ).

When the medical backgrounds of the physicians were examined, the number of active smokers was $32(14.1 \%)$ and the number of physicians who quit smoking was $16(7 \%)$. The smoking rate was $13 \%(\mathrm{n}: 16)$ in females and $17 \%(\mathrm{n}$ : 16) in males and no statistically significant difference was found between genders ( $p>0.05$ ) (Table 2). For family history, the rate of physicians with cancer in their family was $6.2 \%$ (n: 14 ), and $73.1 \%$ without cancer. Forty-six physicians did not answer this question.

When physician's body mass index (BMI) was analyzed, $2.6 \%$ were thin (n: 6), $44.9 \%$ normal (n: 102), $20.7 \%$ overweight (n: 47$), 3.5 \%$ obese (n: 8 ) and $0.4 \%$ morbid obese (n: 1). Male physicians had statistically more fat, and the difference from female physicians was considered statistically significant $(p=0.00)$. When the physicians were grouped 
Table 1. Range of the age of physicians by sex

\begin{tabular}{|c|c|c|c|c|c|c|c|c|c|c|c|c|}
\hline & \multicolumn{10}{|c|}{ Age Range of the Individuals } & & \\
\hline & \multicolumn{2}{|c|}{$23-30$} & \multicolumn{2}{|c|}{$31-40$} & \multicolumn{2}{|c|}{ 41-50 } & \multicolumn{2}{|c|}{$51-60$} & \multicolumn{2}{|c|}{$61-70$} & \multicolumn{2}{|c|}{ Total } \\
\hline & $\mathbf{n}$ & $\%$ & $\mathbf{n}$ & $\%$ & $\mathbf{n}$ & $\%$ & $\mathbf{n}$ & $\%$ & $\mathbf{n}$ & $\%$ & $\mathbf{n}$ & $\%$ \\
\hline Male & 45 & 46.9 & 23 & 24.0 & 17 & 17.7 & 6 & 6.2 & 5 & 5.2 & 96 & 100 \\
\hline Female & 67 & 53.6 & 24 & 19.2 & 26 & 20.8 & 7 & 5.6 & 1 & 0.8 & 125 & 100 \\
\hline
\end{tabular}

Table 2. Smoking status of the physicians by sex

\begin{tabular}{|c|c|c|c|c|c|c|c|c|}
\hline & \multicolumn{6}{|c|}{ Smoking Status } & & \\
\hline & \multicolumn{2}{|c|}{ Smoking } & \multicolumn{2}{|c|}{ Non-Smoking } & \multicolumn{2}{|c|}{ Quitted Smoking } & \multicolumn{2}{|c|}{ Total } \\
\hline & $\mathbf{n}$ & $\%$ & $\mathbf{n}$ & $\%$ & $\mathbf{n}$ & $\%$ & $\mathbf{n}$ & $\%$ \\
\hline \multicolumn{9}{|l|}{ Sex } \\
\hline Male & 16 & 17 & 71 & 76 & 7 & 7 & 94 & 100 \\
\hline Female & 16 & 13 & 98 & 80 & 9 & 7 & 123 & 100 \\
\hline
\end{tabular}

$x^{2}=0.701 ; S D: 2 ; p=0.704$.

according to their age, BMI and age had no statistically significant difference ( $p>0.05$ ).

When the PA chest $x$-rays of physicians were examined, only one radiograph had a "chronic disease sequence", while others were within the physiological limit.

According to the regulation, physicians who need PFT were pathologists, medical oncologists and dentists ${ }^{[5]}$. In the hospital, PFT is performed to the anesthesiology and reanimation clinic physicians, and the dentistry clinic is not available.

It was observed that 76 people out of 81 people who underwent PFT test had normal (88.4\%), three people had obstructive (3.5\%) and two people (2.3\%) had obstructive + restrictive respiratory function. Also, 13 of the physicians (15.1\%) in the risk group who were PFT actively smoked, 60 physicians $(69.8 \%)$ did not smoke, six people (7\%) quit smoking and seven people did not answer the question. When the effects of the independent variable of smoking on PFT results' dependent variable were analyzed, smoking was shown to affect PFT results by $6 \%$. The effects of smoking on pathological findings in PFT are considered statistically significant $(p<0.05)$.

Thyroid USG is carried out for physicians exposed to radiation due to their branches. In the results of USG performed in 20 physicians showed normal results in 13 (5.7\%) physicians, nodules in five (2.2\%) physicians and other pathologies in two (8.8\%) physicians. The biopsy result of a physician with a malignant nodule was malignant and was referred to the relevant branch.

Peripheral smear (PS) is also performed in physicians working in the branches exposed to radiation, and no pathological finding was found in two physicians with PS results. The last two findings were not statistically evaluated due to the lack of data.

\section{Discussion}

In our study, the medical characteristics of physicians, who perform health care duties with great devotion and who are exposed to certain risks at the same time, were analyzed for the risk of cancer. The scope of this analysis is the information obtained in the periodic health examination performed at the Haydarpaşa Numune Training and Research Hospital (TRH). The results, which were accepted as the risk of malignancy, based on the curriculum vitae and physical examination present in the periodic examination files of the physicians, were evaluated.

When the smoking status in the etiology of many malignant diseases, especially respiratory tract cancers, was analyzed, it was observed that the rate of smoking in hospital physicians was $14.1 \%$ (M: $17 \%$, F: $13 \%$ ) In our country, smoking rates in 2016 were $26.5 \%$ in total, $40.1 \%$ in males and $13.3 \%$ in females ${ }^{[10]}$. In general, sex-based smoking rates of hospital physicians were lower than the average of our country, whereas female physicians were similar to the average of our country. Smoking rates among physi- 
cians in our country have a wide range (min. $18.7 \%$-max. $66.2 \%)^{[11,12]}$. It was observed that the general average of actively smoking in hospital physicians was much lower. When we look at the frequency of smoking physicians in the world, a recent study showed $7.8 \%$ of the physicians in Poland ${ }^{[13]}$. The rates were detected as follows: $3 \%$ in Nigeria, 5.3\% in Egypt, $42 \%$ in Canada, 37\% in Pakistan and $38.6 \%$ in Greece ${ }^{[14-18]}$. It is seen that the frequency of actively smoking amongst hospital physicians is lower than the averages of our country, and when compared to the rate of smoking of physicians in other countries, it ranks lower.

When high BMI values, which are risk factors for some malignant diseases, are examined for our study, 20.7\% overweight and $3.9 \%$ obesity rate among physicians were observed. The prevalence of adult obesity in our country, Turkey, was determined to be $29.5 \%$ (female $35 \%$, male $23.9 \%)^{[19]}$. According to our study, the obesity rate was much lower in physicians, and unlike our country, the obesity rate was lower in female physicians than in male physicians. Studies on the physicians' BMI values are rare to come across in the literature ${ }^{[19]}$. A study conducted in the United States (USA) revealed that the rate of overweight was $38 \%$, and the rate of obesity was $15 \%$ in physicians. Taking into consideration the general obesity rate of the US population, this result is not surprising, and our study showed lower rates of obesity ${ }^{[20]}$. However, the results of a recent study have more positive outcomes for the physicians in the US $(29.3 \%$ overweight and $9.1 \%$ obese) ${ }^{[21]}$. In a very recent study conducted in the United Arab Emirates (UAE) revealed that the rate of overweight among physicians was $37 \%$ and the rate of obesity was $12 \%{ }^{[22]}$. The rates determined in our study were found to be much lower. A study looking at the obesity status of resident physicians in our country found that $23.3 \%$ were overweight and $4.7 \%$ were obese ${ }^{[23]}$. In our study, the obesity rate of the resident physicians could not be measured with their PST files because they were classified as only graduate or doctorate graduates, but even so, compared to this study, the obesity rate in our study was low. In a study conducted in Afyon, the obesity rate in physicians was $7.9 \%{ }^{[24]}$. This result includes a higher obesity rate than our study.

When the PA chest $x$-rays available, and useful in the case of a risk of malignancy, in PST files were examined, a "chronic disease sequence" was detected in a radiograph, thyroid USG results and PY findings were also determined to be in a size that could not be evaluated numerically and statistically.

\section{Conclusion}

The profession of medicine is based on devotion and self-sacrifice. Hospitals are considered to have a high risk for occupational health and safety; it is of a great importance that physicians who are responsible for providing the necessary healing process for their patients have routine periodic examinations concerning their own health. Some information and examinations requested during the periodic examination also include risk indicators for malignant diseases. In the analyzes conducted in Haydarpaşa Numune TRH, the prevalence of smoking and obesity, which are the risk factors for malignant diseases, was found to be much lower than the rates of our country. The risk was determined to be much lower in AC radiography, thyroid USG and PY analysis evaluated in the health screenings. The results are considered to have a positive effect on our national data. Broader research on this subject may change the perspective of healthcare professionals on changeable factors in cancer development, and it will enable taking easier steps to reduce environmental triggers.

Ethics Committee Approval: Before this study, the administrative permission of Haydarpaşa Numune Training and Research Hospital, dated 17.09.2018, was obtained.

Peer-review: Externally peer-reviewed.

Authorship Contributions: Concept: H.Ö., M.T.E.; Design: H.Ö., B.U.K.; Data Collection or Processing: B.U.K., S.K., M.M.Y. Analysis or Interpretation: I.G., H.Ö., M.T.E.; Literature Search: H.Ö., S.K., M.M.Y., I.G.; Writing: H.Ö., B.U.K., M.T.E.

Conflict of Interest: None declared.

Financial Disclosure: The authors declared that this study received no financial support.

\section{References}

1. WHO. The top 10 causes of death 2018, https://www.who.int/ news-room/fact-sheets/detail/the-top-10-causes-of-death. Accessed 05.08.2019.

2. WHO. Cancer Tomorow 2019 04.08.2019. Available from: http://gco.iarc.fr/tomorrow/home.

3. TÜiK. Ölüm Nedeni İstatistikleri 2018, http://tuik.gov.tr/PreHaberBultenleri.do?id=30626, Accessed 07.08.2019.

4. Stein $\mathrm{CJ}$, Colditz GA. Modifiable risk factors for cancer. $\mathrm{Br} \mathrm{J}$ Cancer 2004;90:299-303. [CrossRef]

5. T.C. Sağlık Bakanlığı. Hasta ve Çalışan Güvenliğinin Sağlanmasına Dair Yönetmelik 2011, https://dosyamerkez.saglik.gov.tr/ Eklenti/3628,hastavecalisanguvenligininsaglanmasinadairyonetmelikpdf.pdf?0. Accessed 07.08.2019.

6. Wiskar K, BSc. Physician health: A review of lifestyle behaviors and preventive health care among physicians. BC Med J 2012;54:419-23. 
7. George S, Hanson J, Jackson JL. Physician, heal thyself: a qualitative study of physician health behaviors. Acad Psychiatry 2014;38:19-25. [CrossRef]

8. McClafferty $\mathrm{H}$, Brown OW; Section on Integrative Medicine; Committee on Practice And Ambulatory Medicine; Section on Integrative Medicine. Physician health and wellness. Pediatrics 2014;134:830-5. [CrossRef]

9. Schrijver I. Pathology in the medical profession?: Taking the pulse of physician wellness and burnout. Arch Pathol Lab Med 2016;140:976-82. [CrossRef]

10. TÜiK. Türkiye Sağlık Araştırması, 2016, http://www.tuik.gov.tr/ PreHaberBultenleri.do?id=24573. Accessed 30.09.2019.

11. Koç EM, Başer D, Döner P, Yılmaz T, Yılmaz T, Alsancak A, et al. Determining smoking level of hospital employees and the evaluation of the smoke-free air zone applications. J Clin Exp Invest 2015;6:33-9. [CrossRef]

12. Saglam L, Bayraktar R, Kadioglu EE, Acemoglu H. Smoking prevalance and the degree of nicotine dependence among healthcare workers at the ataturk university medical facility. Eurasian J Med 2010;42:74-7. [CrossRef]

13. Jankowski M, Kaleta D, Zgliczyński WS, Grudziąż-Sękowska J, Wrześniewska-Wal I, Gujski M, et al. Cigarette and e-cigarette use and smoking cessation practices among physicians in Poland. Int J Environ Res Public Health 2019;16. pii: E3595.

14. Eldein HN, Mansour NM, Mohamed SF. Knowledge, attitude and practice of family physicians regarding smoking cessation counseling in family practice centers, Suez Canal university, Egypt. J Family Med Prim Care 2013;2:159-63. [CrossRef]

15. Pipe A, Sorensen M, Reid R. Physician smoking status, attitudes toward smoking, and cessation advice to patients: An international survey. Patient Educ Couns 2009;74:118-23.
16. Malik AK, Chaudhry A, Karamat A, Arif N, Cheema MA, Rauf A. Cigarette smoking and health care professionals at Mayo Hospital, Lahore, Pakistan. J Pak Med Assoc 2010;60:509-12.

17. Sotiropoulos A, Gikas A, Spanou E, Dimitrelos D, Karakostas F, Skliros $E$, et al. Smoking habits and associated factors among Greek physicians. Public Health. 2007;121:333-40. [CrossRef]

18. Nollen NL, Adewale S, Okuyemi KS, Ahluwalia JS, Parakoyi A. Workplace tobacco policies and smoking cessation practices of physicians. J Natl Med Assoc 2004;96:838-42.

19. TEMD. Obezite Tanı Ve Tedavi Kılavuzu 2018, http://www.temd. org.tr/admin/uploads/tbl_gruplar/20180525144116-2018-05 25tbl_gruplar144108.pdf. Accessed 09.09.2019.

20. Bleich SN, Bennett WL, Gudzune KA, Cooper LA. Impact of physician BMI on obesity care and beliefs. Obesity (Silver Spring) 2012;20:999-1005. [CrossRef]

21. VanFrank BK, Park S, Foltz JL, McGuire LC, Harris DM. Physician characteristics associated with sugar-sweetened beverage counseling practices. Am J Health Promot 2018;32:1365-74.

22. Nair SC, Sheikh SM, Ibrahim H. Higher physician body mass index is associated with increased weight bias in an arab country with high prevalence of obesity. Int J Prev Med 2019;10:93.

23. Eyüpoğlu A. Eskişehir Osmangazi Üniversitesi Tıp Fakültesi araştırma görevlisi doktorlarının uyku kalitelerinin ve uyku kalitelerine etki edebilecek faktörlerin değerlendirilmesi. Eskişehir Osmangazi Üniversitesi Tip Fakültesi Aile Hekimliği Anabilim Dalı Tıpta Uzmanlık Tezi. 2017. [CrossRef]

24. Efil S. Sağlık çalışanlarında obezite sıklığı ve etkileyen faktörlerin değerlendirilmesi. Afyon Kocatepe Üniversitesi Sağlik Bilimleri Enstitüsü İç Hastalıkları Hemşireliği Anabilim Dalı Yüksek Lisans Tezi. 2006. 